\title{
TINGKAH LAKU MENGUNYAH KERBAU MOA YANG DIBERI HIJAUAN LOKAL DI PULAU MOA KABUPATEN MALUKU BARAT DAYA
}

\author{
C. Ch. E. Latupeirissa ${ }^{1 *)}$, Bercomien J. Papilaya1), Richo P. Lelloltery ${ }^{2)}$ \\ 1) Jurusan Peternakan Fakultas Pertanian, Universitas Pattimura \\ Jln. Ir. M. Putuhena, Kampus Poka, Ambon 97233 \\ 2) Dinas Pertanian Kabupaten Maluku Barat Daya Provinsi Maluku \\ Jl. Tiakur, Kelurahan Tiakur, Moa 97442 \\ *Email : stanslatu@gmail.com
}

\begin{abstract}
ABSTRAK
Penelitian ini bertujuan untuk mengamati tingkah laku mengunyah kerbau Moa yang diberi hijauan lokal dalam bentuk kering. Penelitian menggunakan Rancangan Bujur Sangkar Latin, yang terdiri dari 4 perlakuan dan 4 ulangan. Perlakuan yang dicobakan meliputi A (kombinasi rumput lapangan + daun alumadam), B (rumput lapangan + knumge), C (rumput lapangan + weru), dan D (rumput lapangan). Variabel yang diamati adalah : tingkah laku waktu makan, yang terdiri dari: laju konsumsi, laju mengunyah, efisiensi mengunyah, dan tingkah laku saat ruminasi yaitu laju ruminasi, efisiensi ruminasi, waktu ruminasi/bolus, dan laju regurgitasi. Hasil penelitian menunjukkan bahwa laju konsumsi hijauan untuk perlakuan A, B, C, dan D masing-masing sebesar 31,78, 30,52, 31,99 dan 32,14 g/menit. Laju mengunyah untuk perlakuan A sebesar 50,81, B sebesar 53,94, C sebesar 56,50, dan perlakuan D sebesar 55,67 jumlah kunyahan/menit. Efisiensi mengunyah ((jumlah kunyahan/g BK) hijauan untuk perlakuan $\mathrm{A}=0,23, \mathrm{~B}=0,31$, $\mathrm{C}=0,21$, dan $\mathrm{D}=0,35$. Laju ruminasi (jumlah bolus/menit) untuk perlakuan $\mathrm{A}=1,16, \mathrm{~B}=1,06, \mathrm{C}=1,26$ dan $\mathrm{D}=$ 1,34. Efisiensi ruminasi (jumlah kunyahan/bolus), masing - masing untuk perlakuan A, B, C dan D adalah 37,70, $43,68,36,48$ dan 36,24. Waktu ruminasi (menit/bolus) diperoleh untuk perlakuan $\mathrm{A}=1,14$., $\mathrm{B}=0,96, \mathrm{C}=1,46$, dan $\mathrm{D}=0,44$, sedangkan laju regurgitasi (menit) untuk perlakuan A sebesar 0,16, B 0,89, C 1,46 dan D 0,44. Dari hasil penelitian disimpulkan bahwa kerbau Moa mengkonsumsi hijauan lokal dengan laju dan efisiensi yang sama tetapi mengunyah dengan laju yang berbeda. Selanjutnya laju, efisiensi, dan waktu ruminasi serta laju regurgitasi tidak berbeda.
\end{abstract}

Kata kunci: Kerbau moa, hijauan lokal, tingkah laku mengunyah

\section{THE CHEWING BEHAVIOUR OF MOA BUFFALO FED ON LOCAL FORAGES IN MOA ISLAND MALUKU BARAT DAYA REGENCY}

\begin{abstract}
The objective of the present study is to examine the chewing behaviour of Moa buffalo fed on local forages. The experiment was analysed as Latin square $4 \times 4$, four treatments and four replicates. The treatments were A (combination of graas and aulumadam), B (grass and knumge, C (grass and weru leaves) and D (grass).Variables measured were chewing during eating (intake rate, chewing rate and efficiency) and chewing during rumination (ruminating rate, time spent ruminating per bolus, rumination efficiency, and regurgitation rate). The result show that intake rate was $31.78,30.52,31.99,32.14$ gram/minutes for treatmen $\mathrm{A}, \mathrm{B}, \mathrm{C}$ and $\mathrm{D}$, respectively. Chewing rate (no.of chew/minutes) for A, B, C and D was 50.81, 53.95, 56.50, and 55,67, reapectively, and chewing efficiency (no.of chews/dry weight) was $0.23,0.31,0.21$, and 0.35 for $\mathrm{A}, \mathrm{B}, \mathrm{C}$, and $\mathrm{D}$, respectively. Ruminating rate (no of bolus/minutes) was $1.16,1.06,1.26$, and 1.34 for $\mathrm{A}$. B, C and D, respectively. Ruminating efficiency (no. of chews/bolus) for A, B, C, and D was 37.70, 43.68, 36.48 and 36.24, respectively. Time spent ruminating per bolus was $1.14,0.96,0.82$. and 0.75 minutes for $\mathrm{A}, \mathrm{B}, \mathrm{C}$, and $\mathrm{D}$, respectivly, and regurgitation rate (minutes) was 0.16 , $0.89,1.46$, and 0.44 for $\mathrm{A}, \mathrm{B}, \mathrm{C}$, and D, respectively. It can be concluded than Moa buffalo consume all forages with similar rate and efficiency, while chewing rate differ among the the treatments. Chewing rumination is similar among all forages.
\end{abstract}

Key words: Moa buffalo, local forages, chewing behaviour 


\section{PENDAHULUAN}

Ada dua subspesies utama dari kerbau (Bubalis bubalis) di dunia, yaitu kerbau sungai (River buffalo) dan kerbau lumpur (Swamp buffalo). Kerbau sungai banyak ditemukan di negara-negara Mediteranian, sedangkan kerbau lumpur hanya ditemukan di benua Asia. Saat ini mayoritas dari total populasi kerbau di dunia terdistribusi di Asia, yaitu sekitar 97\% dari stok yang tersedia. Umumnya kerbau-kerbau ini diberi pakan hijauan berkualitas rendah dan limbah tanaman yang bernilai nutrisi rendah sehingga mengakibatkan rendahnya produktivitas dan reproduktivitas (Gautam $e t$ al., 2016). Kerbau merupakan sumber makanan (daging dan susu), tenaga kerja dan juga sumber pupuk organik. Menurut Suhubdy (2017), di negara yang sudah maju sistem peternakannya seperti Amerika dan Australia, kerbau relatif belum diperhatikan dibandingkan dengan ternak sapi (potong dan perah).

Di India, kerbau adalah ternak yang bernilai ekonomis, yang menjadikan negara itu bisa berswasembada daging dan susu (Bunyavejchewin et al., 1994 ; Devendra and Gardiner, 1995). Di Eropa, yang sangat terkenal dengan pengembangan ternak sapinya, kerbau menjadi ternak istimewa terutama di Italia, yang mana kerbau dibudidayakan untuk menghasilkan "mozzarella cheese", produk ternak kerbau yang mempunyai nilai ekonomi sangat strategis (Borghese, 2013). Sama dengan Italia, di Filipina nasib kerbau juga lebih baik dari sapi (Nirmana, 2010), demikian pula di beberapa negara di kawasan Asia lain seperti China, Banglades, Iran, Mesir; nasib ternak kerbau masih lebih baik daripada sapi.

Ternak kerbau di Indonesia tidak seberuntung ternak sapi ((Suhubdy, 2017). Menurut data Direktorat Jenderal Peternakan, populasi kerbau di Indonesia tahun 2008 tercatat berjumlah 2,2 juta ekor, akan tetapi beberapa tahun terakhir populasi kerbau naik turun dan cenderung mengalami penurunan sekitar 8,8\%. Gautam et al. (2016) melaporkan bahwa Indonesia merupakan salah satu dari 11 negara di Asia yang memiliki populasi kerbau sebanyak 1.320 .600 ekor. Faktor-faktor penyebab pertumbuhan populasi kerbau yang kurang menggembirakan antara lain masyrakat memiliki kerbau hanya sebagai keeper (bukan sebagai producer atau breeder), penyusutan luasan padang penggembalaan dan daya dukungnya secara signifikan, penyakit, managemen pemeliharaan yang kurang baik (Diwyanto dan Hadiwirawan, 2006).

Kerbau Moa merupakan salah satu plasma nutfah endemik di pulau Moa, kabupaten Maluku Barat Daya Provinsi Maluku. Kerbau ini berpotensi untuk dikembangkan karena populasinya sekitar 25.000 ekor, bobot badan dewasa (> 3 tahun) $228-310 \mathrm{~kg}$, rataan persentase karkas $55,04 \%$, total produksi mature sekitar 43.200 ton/tahun, dan adanya produksi susu yang dikonsumsi langsung maupun diawetkan oleh peternak. Namun kendala yang dihadapi adalah sistem pemeliharaan yang masih ekstensif, terbatasnya hijauan pakan pada musim kemarau ( $7-8$ bulan), manure yang dihasilkan belum dimanfaatkan secara optimal, teknologi pengawetan susu masih dilakukan secara tradisional (Salamena dan Papilaya, 2010).

Tingkah laku nutrisi termasuk semua aktifitas yang berhubungan dengan menemukan dan memproses nutrien untuk kebutuhan hidup pokok dan produksi; makan, minum, ruminasi dan eliminasi. Kerbau termasuk hewan yang suka merumput kurang memilih dalam mencari makan, sehingga kerbau mengkonsumsi pakan yang kurang bermutu dalam jumlah yang lebih besar dibandingkan dengan sapi. Hijauan merupakan komponen utama dari ternak ruminansia termasuk kerbau yang dipelihara di pulau Moa, jadi karakteristik hijauan yang mempengaruhi konsumsi dan kecernaan nutrisi bersama dengan sifat atau kemampuan ternak mempunyai efek yang penting pada penampilan ternak (fenotip).

Rumput lapangan adalah campuran dari beberapa rumput lokal yang tumbuh secara alami dengan daya produksi dan kualitas nutrisi yang rendah, namun mudah diperoleh, murah dan pengelolaannya mudah. Rumput gajah adalah hijauan yang berkualitas dan disukai ternak, sedangkan kacangan merupakan salah satu hijauan yang mengandung protein lebih tinggi dari pada rumput (Sumarsono, 2002).

Pengunyahan adalah metode utama untuk merusak integritas struktur dan seluler makanan, dan proses ini diikuti dengan hidrasi oleh saliva (Asplund, 1994). Peranan dari pengunyahan adalah menyiapkan makanan untuk ditelan, mengeluarkan kutikula dari struktur tanaman, memisahkan jaringan - jaringan, dan melepaskan nutrien terlarut, meningkatkan area permukaan untuk kolonisasi dengan mikroba rumen dan mengekspose partikel makanan ke komponen dari saliva seperti enzim - enzim pencernaan (Asplund, 1994).

Kerbau Moa, biasanya digembalakan pada pada rumput alam, dan ada beberapa hijauan lokal yang biasa dimakan selain rumut lapangan tanpa ada makanan tambahan. Hijauan lokal yang dimakan oleh kerbau Moa adalah daun aulumadam (Eugenia $s p$ ), daun knumge (Myrtaceae sp.) dan daun weru (Koordesidenron pinnatum). Untuk meningkatkan produktivitas kerbau Moa, perlu dilakukan perbaikan managemen pemeliharaan, salah satu yang sangat urgen adalah managemen pemberian pakan. Dalam praktek sangat sulit untuk memformulasi suatu ransum yang baik karena informasi tentang kualitas hijauan, ketersediaan hijauan yang dapat dikonsumsi dan kemampuan kerbau Moa dalam mendagradasi hijauan sangat terbatas. Selain itu pengetahuan peternak yang kurang tentang tingkah laku biologis ternak juga sering menyebabkan kerbau tidak dapat berproduksi dan bereproduksi seperti yang diharapkan (Handiwirawan $d k k$., 1996). Berdasarkan uraian diatas, maka telah dilakukan penelitian mengenai tingkah laku mengunyah kerbau Moa yang diberi hijauan lokal. Penelitian ini bertujuan untuk mempelajari tingkah laku mengunyah kerbau Moa yang diberi hijauan lokal. 


\section{BAHAN DAN METODE}

Penelitian ini dilakukan di pulau Moa kecamatan Moa - Lakor kabupaten Maluku Barat Daya, berlangsung selama tiga (3) bulan. Metode experimental dengan menggunakan Rancangan Bujur sangkar latin terdiri dari empat perlakuan dan empat ulangan. Perlakuan yang dicobakan adalah perlakuan A (kombinasi rumput lapangan $50 \%+$ daun alumadam $50 \%$ ), B (kombinasi rumput lapangan 50\% + daun knumge 50\%), C (kombinasi rumput lapangan 50\% + daun weru 50\%), dan D (rumput lapangan 100\%), sedangkan ulangannya adalah empat ekor kerbau Moa jantan dewasa, berumur 2 - 3 tahun.

Ternak dikandangkan dalam kandang batu 'lutur'. Semua ternak diberikan kombinasi hijauan secara terpisah dan diberikan dalam bentuk kering (hay). Air minum dan hijauan pakan tersedia secara $\mathrm{ad}$ libitum dan disediakan pada pukul 09.00 pagi. Pengamatan pengunyahan saat makan dan ruminasi dilakukan pada waktu yang berbeda pada hari yang sama untuk setiap individu ternak. Pengamatan dengan menggunakan video kamera. Untuk pengamatan tingkah laku mengunyah waktu makan, sehari sebelum observasi, ternak dipuasakan sepanjang malam. Hari berikutnya, kerbau dikeluarkan dari lutur secara individu ke tempat di mana mereka telah beradaptasi, kemudian diberi $1000 \mathrm{~g}$ dari ransum yang dicobakan dan ternak dibiarkan makan selama 30 menit, waktu dihitung mulai pada saat pengambilan pakan. Pada akhir periode makan, ransum yang tersisa ditimbang dan diambil sampel.

Variabel tingkah laku mengunyah waktu makan, diamati dengan video kamera kemudian dihitung, terdiri dari laju konsumsi (jumlah konsumsi g/menit), laju mengunyah (jumlah kunyahan/menit) dan efisiensi mengunyah (jumlah kunyahan/g bahan kering yang dikonsumsi). Hanya pergerakan rahang selama mastikasi yang dihitung sebagai "kunyahan", tidak termasuk kunyahan yang berhubungan dengan pergerakan rahang saat pengambilan makanan atau minum.

Setelah pengamatan mengunyah waktu makan, kerbau dikembalikan ke dalam lutur, dan diberikan pakan. Aktivitas ruminasi direkam selama 1 jam, untuk tiap ternak, dimulai pada saat kerbau mulai ruminasi. Mengunyah waktu ruminasi, diukur seperti yang digambarkan oleh Howse et al. (1995), dimana jumlah kunyahan selama ruminasi dan waktu yang dibutuhkan dihitung dengan cara mengambil secara acak 25 boli per ternak. Boli diidentifikasi dengan mengamati pergerakan ingesta yang diregurgitasi ke oesophagus. Jumlah kunyahan per boli dihitung dan data diekspresikan sebagai: kecepatan ruminasi (jumlah bolus/menit), efisiensi ruminasi (jumlah kunyahan/bolus yang diamati), waktu ruminasi adalah jumlah waktu yang dipakai (menit/bolus), laju regurgitasi adalah selang waktu diantara dua bolus yang berurutan.

Data dianalisa secara statistik menggunakan Analisis Sidik Ragam, dan jika ada perbedaan dilanjutkan dengan uji Beda Nyata Jujur (BNJ).

\section{HASIL DAN PEMBAHASAN}

Hasil analisis proksimat komposisi kimia (bahan kering (BK), protein kasar (PK), dan serat kasar (SK)) dari hijauan yang dilakukan di laboratorium Kimia Dasar Fakultas MIPA Universitas Pattimura, disajikan dalam Tabel 1 dan hasil perhitungan komposisi kimia (berdasarkan hasil analisa tersebut) dari ransum percobaan diberikan dalam Tabel 2.

Tabel 1, Komposisi Kimia Hijauan

\begin{tabular}{lccc}
\hline \multirow{1}{*}{ Hijauan } & \multicolumn{3}{c}{ Komposisi (\%) } \\
\cline { 2 - 4 } & BK & PK & SK \\
\hline Aulumadam (A) & 85,19 & 10,58 & 23,30 \\
Knumge (K) & 84,71 & 10,69 & 22,55 \\
Weru (W) & 81,68 & 14,02 & 17,87 \\
Rumput lapangan (RL) & 81,28 & 10,86 & 23,65 \\
\hline
\end{tabular}

Tabel 2. Komposisi Kimia Ransum Percobaan

\begin{tabular}{lccc}
\hline \multirow{2}{*}{ Ransum } & \multicolumn{3}{c}{ Komposisi (\%) } \\
\cline { 2 - 4 } & BK & PK & SK \\
\hline A (A 50\% + RL 50\%) & 85,19 & 10,58 & 23,30 \\
\hline B (K 50\% + RL 50\%) & 84,71 & 10,69 & 22,55 \\
\hline C (W 50\% + RL50\%) & 81,68 & 14,02 & 17,87 \\
\hline D (RL 100\%) & 81,28 & 10,86 & 23,65 \\
\hline
\end{tabular}

Tabel 3. Rata - Rata Laju Konsumsi, Laju Mengunyah dan Efiensi Mengunyah Kerbau Moa

\begin{tabular}{cccc}
\hline \multirow{2}{*}{ Ransum } & \multicolumn{3}{c}{ Variabel } \\
\cline { 2 - 4 } & $\begin{array}{c}\text { Laju } \\
\text { konsumsi } \\
(\mathrm{g} / \mathrm{menit})\end{array}$ & $\begin{array}{c}\text { Laju mengunyah } \\
\text { (jml } \\
\text { kunyahan/menit) }\end{array}$ & $\begin{array}{c}\text { Efisiensi } \\
\text { mengunyah } \\
\text { (jml } \\
\text { kunyahan/g) }\end{array}$ \\
\hline $\mathrm{A}$ & $31,78^{\mathrm{a}}$ & $50,81^{\mathrm{c}}$ & $0,23^{\mathrm{a}}$ \\
$\mathrm{B}$ & $30,52^{\mathrm{a}}$ & $53,94^{\mathrm{b}}$ & $0,31^{\mathrm{a}}$ \\
$\mathrm{C}$ & $31,99^{\mathrm{a}}$ & $56,50^{\mathrm{a}}$ & $0,21^{\mathrm{a}}$ \\
$\mathrm{D}$ & $32,14^{\mathrm{a}}$ & $55,67^{\mathrm{ab}}$ & $0,35^{\mathrm{a}}$ \\
\hline
\end{tabular}

$\overline{a, b, c}$ superscipt berbeda pada kolom yang sama menunjukkan berbeda nyata $(\mathrm{p}<0,05)$

\section{Tingkah, Laku Mengunyah Waktu Makan}

Hasil analisis ragam menunjukan tidak ada perbedaan yang nyata dalam laju konsumsi hijauan antara perlakuan $\mathrm{A}, \mathrm{B}, \mathrm{C}$, dan $\mathrm{D}$, akan tetapi hasil penelitian menunjukan bahwa kerbau Moa mengkonsumsi rumput lapangan lebih banyak dibandingkan dengan kombinasi antara rumput lapangan dengan daun aulumadam (Eugenia $s p$ ), dengan daun knumge (Myrtaceae sp) atau dengan daun 
weru (Tabel 3). Faktor yang berkontribusi terhadap laju konsumsi adalah kandungan serat kasar dan protein (McLeod and Smith, 1989 ; Flores, 1991). McLeod and Smith (1989) melaporkan bahwa daun legume dengan kandungan serat kasar yang rendah dikonsumsi dengan laju konsumsi yang tinggi dibandingkan dengan daun rumput dan batang. Flores (1991) menemukan bahwa frekwensi mengunyah dan laju konsumsi tinggi untuk rumput gajah yang memiliki kandungan protein tinggi dan serat kasar yang rendah dibandingkan dengan rumput bahia ketika dimakan oleh domba.

Laju mengunyah kerbau Moa, hasil penelitian ini menunjukan bahwa ada perbedaan yang nyata antara perlakuan $\mathrm{C}$ dan $\mathrm{D}$ dengan perlakuan $\mathrm{B}$ dan $\mathrm{A}$, dan antara $\mathrm{B}$ dan $\mathrm{A}$, sedangkan antara $\mathrm{C}$ dan $\mathrm{D}$ tidak ada perbedaan yang nyata. Hijauan dengan serat kasar yang tinggi, dikonsumsi lebih lambat dan membutuhkan lebih banyak kunyahan (Dulphy and Dorean, 1983 ; Dryden et al., 1995). Terdapat perbedaan dengan penelitian ini yang mengindikasikan bahwa rumput lapangan dengan kandungan serat kasar tertinggi, dikonsumsi lebih banyak per menit, yang artinya laju konsumsinya lebih cepat dari pada perlakuan yang lain. Selanjutnya pada perlakuan $\mathrm{C}$ yaitu kombinasi antara daun weru dan rumput lapangan, yang kandungan proteinnya tinggi dan serat kasar rendah (Tabel 2) dikunyah lebih lambat dan membutuhkan lebih banyak kunyahan dibandingkan dengan perlakuan D (rumput lapangan) meskipun secara statistik tidak berbeda nyata. Demikian juga dengan perlakuan $\mathrm{B}$ (kombinasi rumput langan dan daun knumge) dan perlakuan A (kombinasi rumput langan dan daun aulumadam). Mtengeti et al. (1995) menemukan bahwa meskipun hijauan Trifolus repens yang memiliki kandungan serat kasar lebih rendah dari ryegrass namun domba mengunyah hijauan-hijauan ini dengan kecepatan yang sama. Ini mengindikasikan bahwa bukan saja serat kasar yang mempengaruhi baik laju konsumsi maupun laju mengunyah.

Hal menarik yang ditemukan dalam penelitian ini adalah bahwa ransum dengan kandungan protein yang tinggi dikunyah lebih lama dengan jumlah kunyahan lebih banyak, sedangkan ransum dengan kandungan protein yang rendah dikunyah lebih cepat dengan jumlah kunyahan lebih sedikit. Hal ini konsisten dengan apa yang dilaporkan oleh Latupeirissa (2009) bahwa hay alfalfa yang mempunyai kandungan serat kasar rendah dan protein yang tinggi dikunyah lebih lambat dari hay rhodes grass dan jerami barley yang mempunyai kandungan serat kasar lebih tinggi dan protein yang rendah.

\section{Tingkah Laku Mengunyah Saat Ruminasi}

Ruminasi memegang peranan penting dalam mengurangi ukuran partikel makanan yang tidak dapat dipecahkan menjadi kurang dari 1,0 mm selama proses mengunyah waktu makan (Ulyatt, 1983 ; Kennedy, 1985 ; Ulyatt et al., 1986 ; Domingue et al., 1991). Ruminasi menghabiskan $60-70 \%$ dari waktu ternak kerbau makan selama siang hari, mereka menghabiskan lebih banyak waktu ruminasi pada malam hari dibandingkan siang hari. Kerbau menghabiskan lebih sedikit waktu ruminasi daripada ternak lain (Currie, 1988 dalam Ibrahim et al., 2001). Proses ruminasi berjalan kira-kira 15 kali sehari, dimana setiap ruminasi berlangsung 1 menit sampai 2 jam (Prawirokusumo, 1994).

Tabel 4. Rata - Rata Laju, Efisiensi, Waktu Ruminasi, dan Laju Regurgitasi

\begin{tabular}{|c|c|c|c|c|}
\hline \multirow[b]{2}{*}{ Ransum } & \multicolumn{4}{|c|}{ Variabel } \\
\hline & $\begin{array}{c}\text { Laju } \\
\text { rum. } \\
\text { (bls/m) }\end{array}$ & $\begin{array}{c}\text { Efisiensi } \\
\text { rum. } \\
\text { (knyhn/b } \\
\text { ls) }\end{array}$ & $\begin{array}{c}\text { Waktu } \\
\text { rum } \\
(\mathrm{m} / \mathrm{bls})\end{array}$ & $\begin{array}{c}\text { Laju } \\
\text { reg } \\
\text { (menit) }\end{array}$ \\
\hline A & $1,16^{\mathrm{a}}$ & $37,70^{\mathrm{a}}$ & $1,14^{\mathrm{a}}$ & $0,16^{\mathrm{a}}$ \\
\hline B & $1,06^{\mathrm{a}}$ & $43,68^{\mathrm{a}}$ & $0,96^{\mathrm{a}}$ & $0,89^{\mathrm{a}}$ \\
\hline $\mathrm{C}$ & $1,26^{\mathrm{a}}$ & $36,48^{\mathrm{a}}$ & $0,82^{\mathrm{a}}$ & $1,46^{\mathrm{a}}$ \\
\hline $\mathrm{D}$ & $1,34^{\mathrm{a}}$ & $36,24^{\mathrm{a}}$ & $0,75^{\mathrm{a}}$ & $0,44^{\mathrm{a}}$ \\
\hline
\end{tabular}

Data pada Tabel 4 menunjukan bahwa tidak ada perbedaan yang nyata di antara perlakuan baik untuk laju ruminasi, efisiensi ruminasi, waktu ruminasi dan laju regurgitasi. Namun demikian secara numerik ada perbedaan rata-rata antar perlakuan. Kerbau Moa, mengunyah lebih banyak bolus per menit ketika mengkonsumsi rumput lapangan dibandingkan dengan ransum lainnya, artinya laju ruminasi pada perlakuan $\mathrm{D}$ lebih cepat diikuti oleh perlakuan $\mathrm{C}$ (kombinasi rumput lapangan dan daun weru), perlakuan A (kombinasi ketika rumput lapangan dan daun aulumadam), dan yang terrendah adalah perlakuan B (kombinasi rumput lapangan dan daun knumge).

Pola laju ruminasi sejalan dengan pola laju konsumsi (Tabel 3), dimana kerbau Moa mengkonsumsi rumput lapangan (perlakuan D) lebih cepat daripada kombinasi rumput lapangan dan daun weru, kombinasi rumput lapangan dan daun aulumadan, dan kombinasi ruput lapangan dan daun knumge. Demikian pula waktu yang diperlukan untuk mengunyah satu bolus yang diruminasi lebih pendek ketika kerbau Moa memakan rumput lapangan dibandingkan dengan perlakuan lainnya. Hal ini menunjukan bahwa bukan kandungan serat kasar hijauan tidak mempengaruhi baik laju konsumsi maupun laju ruminasi, artinya hal ini disebabkan oleh faktor-faktor lain, mungkin tekstur dari hijauan lokal yaitu daun weru, knumge dan aulumadam atau mungkin kandungan komponen serat kasar dari hijauan-hijauan tersebut, sehingga ternak kerbau Moa kesulitan dalam membentuk dan mengolah bolus. Hal ini perlu dipelajari lebih lanjut, karena dalam penelitian ini tidak menganalisa komponen serat kasar.

Selain mengunyah lebih banyak bolus per menit, kerbau Moa membutuhkan lebih sedikit kunyahan per bolus saat diberi rumput lapangan dibandingkan ketika 
diberi kombinasi rumput lapangan dengan daun weru (perlakuan C), aulumadan (perlakuan A) dan knumge (pelakuan B), artinya kerbau Moa lebih efisien dalam mengunyah rumput lapangan ketika ruminasi dibandingkan dengan perlakuan yang lain. Dengan demikian kandungan serat kasar hijauan tidak secara langsung mempengaruhi baik laju konsumsi, laju ruminasi maupun waktu ruminasi. Terdapat kemungkinan faktor-faktor lain seperti tekstur hijauan lokal (daun weru, knumge dan aulumadam), atau mungkin kandungan komponen serat kasar dari hijauan-hijauan tersebut, sehingga ternak kerbau Moa mengalami kesulitan dalam membentuk dan mengolah bolus. Hal ini perlu dipelajari lebih lanjut, karena dalam penelitian ini tidak dianalisa komponen serat kasar.

Interval waktu antara bolus lebih panjang pada kerbau Moa yang mengkonsumsi kombinsi antara rumput lapangan dan daun weru dibandingkan dengan perlakuan yang lain. Ibrahim et al. (2001) mengatakan bahwa waktu yang dihabiskan untuk ruminasi tergantung pada asupan dinding sel dalam pakan dan umumnya dibagi menjadi berbagai periode diselingi dengan interval makan, minum dan istirahat.

\section{SIMPULAN DAN REKOMENDASI}

Berdasarkan hasil dan pembahasan yang telah dikemukakan maka dapat disimpulkan bahwa; (1) kerbau Moa mengkonsumsi hijauan lokal dengan laju konsumsi dan efisiensi yang sama, tetapi dengan laju mengunyah yang berbeda ; dan (2) tingkah laku ruminasi kerbau Moa yaitu laju dan efisiensi ruminasi, waktu ruminasi dan laju regurgitasi tidak berbeda secara nyata ketika diberi hijauan lokal.

Tingkah laku makan seperti aktivitas makan dan ruminasi kerbau Moa sepanjang hari belum pernah dilakukan, sehingga disarankan untuk dilakukan penelitian lanjutan.

\section{DAFTAR PUSTAKA}

Asplund, J. M. 1994. Structure and Function of The Ruminat Digestive Tract. In Principles of Protein of Ruminant Nutrition (Ed. J. M. Asplund). p. 5 - 28. Boca Raton: CRC Press. Inc.

Borghese, A. 2013. Buffalo Livestock and Products. Consiglio Per la Ricerca e la Sperimentazione in Agricoltura (CRA), Rome, Italy.

Bunyavejchewin, P., C. Chantalakhana, and S. Sangdid. 1994. Long-term Genetic Improvement of the Buffalo. Proceedings of the First ABA (Asian Buffalo Association) Congress. 226 p. held during 17-21 January 1994 in Khon Kaen, Thailand.
Devendra, C., and P. Gardiner. 1995. Global Agenda for Livestock Research. Proceedings of the Consultation for the South-East Asian Region. 280 p. 10-13 May 1995, IRRI, Los Banos, The Philippines.

Domingue, B. M. F., D. W. Dellow, and T. N. Barry. 1991. The Efficiency of Chewing During Eating and Ruminating In Goats and Sheep. Britsh Journal of Nutrition. 65: 355-363.

Dryden, G. McL., K. J. Stafford, G. C. Waghorn, and T. N. Barry. 1995. Communition of Roughages By Reed Deer (Cervus Elaphus) During The Prehension of Feed. Journal of Agricultural Science. 123: 407-414.

Dulphy, J. P., and B. M. Dorean. 1983. Compartement alimentaire et merycique d'ovins recevant des fourrages verts. Annals de Zootechnie. 32: 465474.

Dwiyanto, K., dan E. Handiwirawan. 2006. Strategi Pengembangan Ternak Kerbau: Aspek penjaringan dan distribusi. Pros. Lokakarya Nasional Usaha Ternak Kerbau Mendukung Program Kecukupan Daging Sapi. Hal. 3-12. Sumbawa, 4-5 Agustus 2006.

Flores, C. J. A. 1991. Determinants of The Difference In Forage Quality Between Pensola Bahiagrass (Paspalum natatum Flugge) and Mott Dwarf Elephant Grass (Pennisetum purpureum, Schum). [Thesis]. Florida: University of Florida.

Gautam, K. D., N. N. Talukder, G. Duran, and G. A. Presicce. 2016. Safe and Sustainable Traditional Production: The Wate Buffalo in Asia. Frontiers in Environmental Science. 4(38): 1-7. DOI: 10.3389/fenvs.2016.00038.

Handiwirawan, E., B. Setiadi, dan D. Anggraeni. 1996. Produktivitas Induk Ternak Ruminansia Kecil Pada Kondisi Peternakan Rakyat Di Kabupaten Lebak. Prosiding Seminar Nasional Peernakan dan Veteriner. Hal. 184187. Bogor: Pusat Penelitian dan Pengembangan Peternakan.

Howse, A. J., G. Semiadi, K. J. Stafford, T. N. Barry, and P. D. Muir. 1995. Digestion and Chewing Behaviour of Young Sambar and Red Deer Consuming Low-Quality Roughage. Journal of Agricultural Science Cambridge. 125: 399405.

Ibrahim, M. N. M., K. K. Pathirana, and J. A. D. Siriwardene. 2001. Water Buffalo in Asia. Sri Langka: National Science Foundation.

Kennedy, P. M. 1985. Effect of Rumination On The Reduction of Particle Size of Rumen Digesta 
By Cattle. Australian Journal of Agricultural Research. 36: 819-828.

Latupeirissa, C. Ch. E. 2009. Rumination Behaviour of Rusa Deer and Merino Sheep Fed Different Forages. Makila. 3(2): 36-45.

Mc Leod, M.N., and B. R. Smith. 1989. Eating and Ruminating Behaviour In Cattle Given Forages In Fibre Content. Animal Production. 48: 243-249.

Mtengeti, E. J., D. Wilman, and G. Moseley.1995. Physical Structure of White Clover, Rape, Spurrey and Perennial Ryegrass In Relation To Rate of Intake By Sheep, Chewing Activity and Particle Breakdown. Journal of Agricultural Science Cambridge. 125: 43-50.

Nirmana. 2010. Ruminant Animal Industry Road Map 2010-2034. Filipina: Philippine Carabau Center (PCC).

Prawirokusumo, S. 1994. Ilmu Gizi Comparatif. Yogyakarta: Gadjah Mada University Press.

Salamena, J. F., dan B. J. Papilaya. 2010. Characterization and Genetic Relationship Analysis of Buffalo Population In Moa Island of South East-West Maluku Regency of
Maluku Province. Journal Indonesia Tropical Agri. 35 (2): 75-82.

Suhubdy. 2017. Skenario Pengembangan Ternak Kerbau dan Sapi di Indonesia. Proseding Seminar Nasional III Sapi dan Kerbau. ISBN :978-602-6953-216. Hal.1-15. Hotel Grand Inna Muara, Padang, 4-5 Oktober 2017.

Sumarsono. 2002. Ketahanan Sentro (Centrosema pubescens, Benth) dalam Pertanaman Campuran dengan Menerima Pupuk Fosfat dan Kotoran Ternak. J. Peternakan Tropis. 27(2): 76-82.

Ulyatt, M. J. 1983. Plant fibre and regulation of digestion in the ruminant. In fibre in human and animal nutrition (Eds. G. Wallace and I. ., Bell) pp. 103-107. The Royal Society of New Zealand, Bulletin 20, Wellington, NZ: Society of New Zealand.

Ulyatt, M. J., D. W. Dellow, C. S. W. Reid, and G. C. Waghorn. 1986. Contribution of chewing during eating and rumination to the clearance of digesta from the reticulorumen. In Control of Dgestion and Metabolism in Ruminant. (Eds. L.P. Milligan, W.L. Grovum and A. Dobson) pp. 498-515. Englewood Cliffs NJ: Prentice Hall.

Available online at journal homepage: http://ojs3.unpatti.ac.id/index.php/agrinimal 